\title{
In the Shadow of Ultra: A Reappraisal of German Naval Communications Intelligence in 1914-1918
}

\section{Keith W. Bird and Jason Hines}

Cet article traite des lacunes de longue date dans l'histoire des renseignements sur les communications (Funkaufklärung) au sein de la marine impériale allemande pendant la Première Guerre mondiale - un sujet que David Kahn a décrit comme étant " parmi les plus grands chaînons manquants de l'histoire de la cryptologie ». Les auteurs examinent d'abord la documentation actuelle concernant les renseignements sur les communications navales allemandes, y compris l'évaluation officielle réalisée par la marine en 1934 de l'influence des renseignements sur les communications sans fil pendant la guerre. Ils décrivent ensuite l'évolution formatrice de la structure des renseignements sur les communications de la marine impériale au début de la Première Guerre mondiale ainsi que son utilisation des moyens de cryptologie qui étaient en rapide évolution. Leur analyse est fondée sur de nouvelles recherches réalisées à partir des dossiers originaux du service de décryptage de la marine impériale et de sources de renseignements américaines.

\section{Introduction}

The purpose of this article is to discuss the long-standing gap in the history of communications intelligence (Funkaufklärung in German or "radio intelligence") in the Imperial German Navy during the First World War-a topic described by the dean of cryptologic historians, David Kahn, as "perhaps one of the greatest missing links in cryptologic history." "The authors will approach the topic from

1 David Kahn's assessment, 'Editor's Note' to Hilmar-Detlef Brückner, "Germany's First Cryptanalysis on the Western Front: Decrypting British and French Naval Ciphers in World War I,"

The Northern Mariner / Le marin du nord, XVIII, No. 2 (Spring 2018), 97-117 
two directions: through an examination of the existing literature on German naval communications intelligence, including the navy's 1934 official evaluation of the influence of wireless during the war, and through the prism of new research in the original archival files (reports, memorandums, telegrams and letters) of the Imperial Navy's decryption service and US intelligence sources. ${ }^{2}$ With these insights provided by these two approaches, the authors will describe the formative development of the Imperial Navy's communications intelligence structure and activities in the First World War and its use of the rapidly changing tools of cryptology. ${ }^{3}$

Wireless telegraphy (W/T, later referred to as radio) quickly became a critical source of intelligence in the First World War, dramatically changing the nature of naval warfare. As one leading participant in Germany's development of communications intelligence in the period 1914-1945 noted, the practice of "disguising" one's radio traffic and the use of cryptologic systems was "much more intensive and on a larger scale at sea than on land." 4 The navy employed wireless extensively for command and control, especially in the tightly coordinated tactics favoured by the High Seas Fleet..$^{5}$ The collection of enemy wireless message traffic enabled the Imperial Navy to provide its fleet (in particular, the operational commanders and U-boat captains) with operational intelligence (e.g., the location of enemy ships and minefields) that would be a major asset in the U-boat war. However, the navy's frequent and undisciplined use of wireless would create a

Cryptologia, 5:1 (January 2005), 1. Markus Pöhlmann's “Towards a New History of German Military Intelligence in the Era of the Great War: Approaches and Sources," The Journal of Intelligence History, 5:1 (Winter 2005), i-viii, regards the current knowledge of German military intelligence history as "extremely limited" and "chronically distorted." The term communications intelligence (COMINT) is often used as a synonym of signals intelligence (SIGINT) but it is a subfield of that broader area.

2 Gustav Kleikamp, "Der Einfluß der Funkaufklärung auf die Seekriegführung in der Nordsee 19141918. Geheim. MDv. 352, Dienstschrift Nr. 13, Leitung der Führergehilfenausbildung der Marine," (Berlin, 1934). The authors are indebted to the Bibliothek für Zeitgeschichte-Württembergischen Landesbibliothek for making this document available. A copy of Kleikamp's "Dienstschrift" is also available in the National Archives and Records Administration, College park, Maryland (NARA), Item 9032-208, Record Group 457, Entry A1 9032, Records of the National Security Agency/Central Security Service (NSA/CSS).

3 When the First World War began, there was no organized radio intelligence service, only the B-Dienst (Beobachtungsdienst or Monitoring Service) based at the coastal radio station at Helgoland and on-board ships (Bord-B-Dienst). For the origins of the Admiralstab's human intelligence (HUMINT) organization from 1901, the Nachrichtenabteilung (N), see Thomas Boghardt's Spies of the Kaiser (Basingstoke, UK: Palgrave Macmillan, 2004). Markus Pöhlmann's "German Intelligence at War, 1914-1918," Journal of Intelligence History 5:2 (Winter 2005), 25-54, an excellent summary of the overall German military's approach to intelligence assessment and includes a brief overview of signals intelligence in the war.

4 Wilhelm F. Flicke, "War Secrets in the Ether" Parts I and II. Trans. by Ray W. Pettengill. Washington D.C., 1953,NARA, NSA, REF ID: A59421, declassified 29 January 2014, Internet Archive, https://archive.org/details/41761019080017/page/n0 (accessed September 27, 2017).

5 Daniel R. Headrick, The Invisible Weapon: Telecommunications and International Politics 1851-1945 (Oxford: Oxford University Press, 1991), 157. 
major security problem, and a rich opportunity that the Royal Navy's cryptologic unit, Room 40, would quickly exploit, especially after the chance acquisition of German codebooks. In the naval war, intelligence became "as important as strategy and armaments." 6

The use of enemy wireless transmissions to locate ("fix" in intelligence parlance) and plot the direction of enemy forces would also be important in the war and by 1915, both the British and Germans had created a network of stations for direction finding (D/F). Geographically, the British held an advantage by being able to cover a broader arc than Germany's intercept stations, whose narrow coastline limited coverage and effectiveness. Technical improvements in equipment increased the accuracy in finding the position of a ship (by one estimate) to within twenty miles in the North Sea and within fifty miles in the Atlantic and became especially critical for Germany's U-boat war against commerce.

Believing their direction-finding to be inferior to the British, the Germans were inclined to accept that British successes in finding their forces were the result of $\mathrm{D} / \mathrm{F}$ (just as they thought radar was a major cause of their losses in the Second World War). This offered the British a ready deception to protect the source of their intelligence (i.e. code-breaking) - a ruse they used in both world wars. ${ }^{8}$ While the German navy had worked with Telefunken as the supplier of its wireless equipment and technology improvements during the war, the Royal Navy had likewise reaped benefits early from its close association with Marconi beginning in 1896 and had access to the latest scientific, engineering and technical resources as well as wireless stations in England and the Mediterranean throughout the war. ${ }^{9}$

This article also adds an important new perspective on how the fragmented German military and naval commands afflicted the Imperial Navy on both the strategic and tactical level, demonstrating the importance and difficulty of integrating communications intelligence into the conduct of the naval war. Moreover, the implications of the navy's experiences in the First World War foreshadowed similar critical flaws in the German approach to broader signals

6 Ibid. Headrick argues that the British command of the sea "hinged on superior naval intelligence" as well as having a larger fleet.

7 Ibid., 158-159.

8 Ibid., 158 and Beesly, Room 40 British Naval Intelligence 1914-18 (San Diego, New York and London: Harcourt, Brace Jovanovich, revised US edition, 1982) 69-71. Kleikamp, 9, believed the British developments in D/F had antedated Germany's efforts and were "much superior" but Patrick Beesly thought they had both started around the same time. Beesly, 69. See Kleikamp, passim and Jason Hines, "Sins of Omission and Commission: A Reassessment of the Role of Intelligence in the Battle of Jutland," Journal of Military History 72:4 (October,2008), 1117-1154. The Admiralty felt that D/F would prove a good cover for Room 40's efforts and included wording in Admiralty messages to Jellicoe attributing intelligence to "directionals" (D/F). See Sir Alfred Ewing, "Some Special War Work," reproduced in "Alfred Ewing and 'Room 40"” Notes and Records of the Royal Society of London 34:1 (July 1979), 84 and Beesly, 70.

9 For Marconi and his work with the Royal Navy, see James Wyllie and Michael Mckinley, Codebreakers. The Secret Intelligence Unit that Changed the Course of the First World War (London: Ebury Press, 2016), 9-10. 
intelligence in the Second World War as it became increasingly dependent upon radio for command and control as well as intercepting enemy radio traffic. Although acutely aware during the war of the British success in breaking their codes and their own shortcomings in communications security in the naval war of 1914-1918, the German Naval High Command in the Second World War proved unable once again to evaluate objectively the possibility that their enemies would compromise their communications security to a significant degree. David Kahn called the Imperial Navy's three-year delay in addressing their security problems "as one of the greatest security failures in history." 10

\section{Communications Intelligence in Literature and Research}

During the inter-war period, while the British Admiralty tried to prevent any disclosure of Room 40's cryptanalysis activities in the First World War for security and political reasons, various accounts from both the British and German sides referenced the use of wireless in fleet operations and codebreaking. These included notable early post-war memoirs by Winston Churchill and Admirals Jellicoe and Scheer. British and German histories also had limited details of the role and exploitation of wireless in the war at sea (including deliberate omissions). Throughout the 1920s and 1930s, the British not only attempted to suppress the full extent of Room 40's codebreaking but also sought to downplay the submarine threat to England, hoping thereby to discourage future enemies. The Admiralty feared that a public disclosure of Room 40's successes would create embarrassing questions given the controversy over intelligence during the public debate over the Royal Navy's "failure" to defeat the German fleet decisively or reveal Room 40's role in exposing the infamous Zimmermann Telegram. ${ }^{11}$ Nevertheless, anyone could read between the lines in Brassey's Naval Annual in 1919 of the "persistent and ubiquitous knowledge" that the British "Intelligence Division" appeared to have about "every movement" of the Germans which had successfully "paralysed" the initiative of the High Seas Fleet, even if these comments did not reveal the extent and source of such knowledge. ${ }^{12}$ By the early 1920s, the German navy had taken steps to improve security adopting the electro-mechanical Enigma encryption machine, the first navy to use modern cipher machines operationally.

10 David Kahn, Seizing the Enigma: The Race to Break the German Codes 1939-1943 (Annapolis: Naval Institute Press, 2012), 34. It was not until the summer of 1917 before the Imperial Navy released two new signal books to complicate Room 40's decryption of its messages.

11 Hans Joachim Koerver, German Submarine Warfare 1914-1918 in the Eyes of British Intelligence (Steinbach: LIS Reinisch, 2012), ix-x. Cf. Beesly. For the most complete account of Room 40's role in the Zimmermann telegram, see Thomas Boghardt, The Zimmermann Telegram: Intelligence, Diplomacy and American's Entry into World War I (Annapolis: Naval Institute Press, 2012).

12 See Robert M. Grant, U-Boat Intelligence 1914-1918 ( Hamden, CT: Archon Books, 1969), 166-167. Grant cites the 1919 Brassey's Naval Annual for noting that it was German naval officers after the war who commented on how quickly the British knew of their operations. 
Despite British efforts, though, several significant leaks in the mid-1920s provided concrete evidence to the German intelligence services of the scale and ease with which the British had broken their codes throughout the war. ${ }^{13}$ In response, the Germans dramatically improved their military and diplomatic cryptography after 1925 and sharply limited talk of their cryptographic innovations, backed up by the 1914 wartime secrecy law. ${ }^{14}$

While the Second World War dominated much of the attention of naval historians after 1945, there was little discussion of codebreaking in the earlier naval war against Germany. A limited number of historians received access to more information about the Admiralty's communications intelligence organization, known as Room 40. Among these was the American authority on the Royal Navy, Arthur J. Marder, whose second edition of his magnum opus, From the Dreadnought to Scapa Flow, criticized the disconnect between "enemy reporting" and "action information" between the cryptographers, the Admiralty's Operations Staff and the operational commanders..$^{15}$ His contemporary and rival, Stephen Roskill, the British naval officer and historian, was certainly privy to details of British codebreaking in both world wars as were the participants themselves but there was little elaboration of codebreaking other than hints that there was more to the story. Robert Grant, who published U-Boat Intelligence in 1969, acknowledged the help he had received from Marder and British historians and naval officers in addition to records from the captured German archives and the French Ministry of the Navy. Admiral Sir William James, who had overseen Room 40's decryption late in the war as a commander, also assisted him in accessing some of the British intelligence files. While Grant cited documents that the British had obtained valuable intelligence on the German navy in 1914-1918 and used it effectively to defeat the U-boats, he was still unable to penetrate completely the British veil of secrecy on the extent of its cryptographic successes.

Although some of the post-war histories (published before the Ultra revelations) had cast new light on the role of decryption in the First World War, it would not be until the 1970s that the closely-guarded secret of Allied code breaking during the Second World War became public knowledge. ${ }^{16}$ Many studies concentrated on the

13 See “The Room 40 Compromise,"NSA,DOCID 3978516, (declassified 2012).https://www.nsa. gov/news-features/declassified-documents/nsa-60th-timeline/assets/files/1960s/19600101_1960_ Doc_3978516_Room40.pdf accessed 23 April 2018. A court case in 1927 revealed over 10,000 Room 40 decrypts demonstrating British cryptography expertise. In December 1927, former head of Room 40, Sir Alfred Ewing's ill-advised public lecture came to the attention of German intelligence through the British press coverage.

14 Ibid.

15 See, for example, comments by Arthur J. Marder, From the Dreadnought to Scapa Flow vol 3, 2nd rev. and exp. ed. (Oxford: Oxford University Press, 1978) 5-47, 217, 269-270. See also Barry Gough's "Introduction" for his summary of Marder's view's on Jutland as an intelligence failure per the revised vol 3 in the joint Naval Institute Press/Seaforth Publishing 2014 softcover reissue.

16 See F.W. Winterbotham's popular exposé, The Ultra Secret (New York: Harper \& Row, 1974), and Jürgen Rohwer's "Ultra and the Battle for the Atlantic: the German View," in Robert William Love Jr., ed., Changing Interpretations and New Sources in Naval History (New York, 1980), 420- 
decisive role special intelligence played in the Allied victory in the Second World War, especially the defeat of the U-boats, but it was not until 1982 that the leading authority on British naval intelligence, Patrick Beesly, published a comprehensive history of Room 40.

He brought to public notice the existence an unpublished 1920s classified history of Room 40 by William Clarke and Frank Birch with a supporting set of documents that highlighted the war-shortening success of British codebreaking. His focus on Room 40 and his limited use of sources on the German side, restricted to Kleikamp, did not allow him to explore the complex reasons for the German navy's intelligence failures more fully.. ${ }^{17}$

Reflecting the increasing volume of open records available at the British National Archives and other archives since 1985, a wide spectrum of other scholarly or popular studies began to fill in the details of codebreaking in the First World War , primarily from the British perspective. In 1985, Alberto Santoni published "The First Ultra Secret," the result of his detailed research into the available British records on the influence of codebreaking in the First World War. ${ }^{18}$ In 2003, Grant showed how new material had advanced the story of Room 40. Updating his pioneering 1969 study of U-boat intelligence, he shed new light on aspects of how the British deciphered German U-boat signals and what use they made with this intelligence in operations. Grant highlighted the many intelligence sources the British collected from salvaging sunken U-boats and downed Zeppelins, prisoner interrogations, intercepts and decryptions of German naval messages and traffic analysis. The results enabled the British to use operational intelligence to disrupt German minelaying efforts significantly, and to find U-boats vulnerable to attack or to re-route convoys away from U-boat patrol areas. ${ }^{19}$

In addition to the growing number of monographs on the work of Room 40, several seminal specialized articles offer new perspectives into the British-German intelligence war. In 1987, Nicholas Hiley argued that the original purpose of Room

443. The best summary of the historiography of Ultra and the questions/methodologies that scholars need to consider in evaluating the role of signals intelligence in both World Wars is W. J. R. Gardner's seminal analysis, Decoding: The Battle of the Atlantic and Ultra (Annapolis: Naval institute Press, 1999).

17 Among the many studies of Room 40 since Beesly's 1982 book, see David Ramsay's excellent 2009 biography of Admiral Sir Reginald "Blinker" Hall, 'Blinker' Hall, Spymaster: The Man Who Brought America into the War (Stroud, Gloucestershire, UK: Spellmount, rev. ed. 2009). He was considered the genius behind the development of British naval intelligence. Ramsay had access to new source material not available to Beesly.

18 Alberto Santoni, Il primo ULTRA Secret. L'influenza delle decrittazioni britanniche sulle operazioni navali della guerra 1914-1918 (Milan: Mursia, 1985). See also his summary, "The First Ultra Secret: The British Cryptanalysis in the Naval Operations of the First World War," Revue internationale d'histoire militaire, No. 63 (October 1985), 99-110.

19 Robert M. Grant, The U-boat Hunters: Code Breakers, Divers and the Defeat of the U-boats, 1914-1918 (Annapolis: Naval Institute Press, 2003), is invaluable for its assessment of the range of sources available in 2003 including the records of the Post Office Archives in London and includes a revised list of U-boats, sunk or interned. 
40 was to intercept German military, political and diplomatic signals from the shore-based high-power long-wave German radio transmitters. However, the British disruption of the German strategic communications at the outbreak of the war and the acquisition of the German codebooks quickly enabled Room 40 to take advantage of the Imperial Navy's prolific use of wireless for "a more profitable area of study" of the tactical signals of the German High Seas Fleet. ${ }^{20}$

Jonathan Reed Winkler's 2009 article showed the scale of the long-neglected aspect of the British and German global communications war that affected operations as well as efforts to influence diplomatic and economic relationships. While the British were more prepared to launch a devastating strategic communications blockade, Winkler's research suggests the German efforts, albeit under-resourced, were also intended to conduct a world-wide information war (including using U-boats to cut enemy cables). Germany's subsequent communications isolation left them dependent upon their high-power radio transmitters to overcome their political, military, and economic isolation, contributed to their dependence upon wireless thereby increasing the importance of Room 40's work. ${ }^{21}$

Nicholas A. Lambert's award-winning research into the development of the Admiralty's system of strategic naval command and control brought new insights into the revolutionary impact of wireless to create the first example of "information dominance" through the adoption of the "War Room" system. Thus, Britain used its advantage in global communications and the centralization of global intelligence for a strategy of manoeuvre warfare. Lambert argued that Room 40 was a part of a larger "preexisting information processing organization." 22 The role of intelligence at Jutland has also received a new assessment through Jason Hines' 2008 study. Hines highlighted the challenges both fleets faced and suggests another perspective to the commonly-held interpretation that British intelligence had failed at Jutland. In deciding whether and how to disseminate reports based on communications intelligence, the Admiralty placed more emphasis on the security of its intelligence source than on its operational use. To protect their source, the Admiralty carefully sanitized Room 40 intelligence in a way that either caused confusion or a loss of credibility with the fleet commanders. ${ }^{23}$

Unlike the files of the British War Department's Military Intelligence Office, destroyed at the end of the First World War, the surviving documents of Room

20 Nicholas Hiley, "The Strategic Origins of Room 40," Intelligence and National Security 2:2 (1987), 245-273.

21 Jonathon Reed Winkler, "Information Warfare in World War I," Journal of Military History 73:3 (July 2009) , 845-867.

22 Nicholas A. Lambert, "Strategic Command and Control for Maneuver Warfare: Creation of the Royal Navy's 'War Room' System, 1905-1915,' Journal of Military History 62:2 (2005), 361410. This won the 2004 Julian Corbett Prize in Modern Naval History

23 Hines, 1133-4. Newer studies of First World War's fleet engagements reflect the increased attention paid to the role of wireless and its "operational challenges." See James Goldrick, Before Jutland (Annapolis: Naval Institute Press, 2015) and John Brooks's The Battle of Jutland (Cambridge: Cambridge University Press, 2016). 
40 were extensive, even with the usual culling. ${ }^{24}$ In 2007-2009, Hans Joachim Koerver edited Room 40's unpublished history of the German fleet as seen through the records of Room 40, "Contribution to the History of German Naval Warfare 1914-1918," as Room 40: German Naval Warfare 1914-1918 in two volumes. For security reasons and the desire to avoid raising embarrassing questions about the lack of coordination between Room 40, the Admiralty and Fleet Command, the Admiralty had withheld any public references to Room 40's official study until Patrick Beesly's citation in his 1982 Room 40. Based on the extensive amounts of data and information gathered from all intelligence sources including some 200,000 deciphered German wireless naval and diplomatic messages, this trove revealed an amazing knowledge of all aspects of the Imperial Navy's organization, personnel, construction, strategy, tactics and operations of its ships, U-boats and Zeppelins. ${ }^{25}$ In 2012, Koerver published his encyclopaedic German Submarine Warfare 1914-1918 in the Eyes of British Intelligence, a seven hundred page guide that brought together the deciphered wireless intercepts, intelligence reports and interrogations of prisoners and survivors. He also included details about U-boat design and construction and the submarine war with a rich collection of data showing ships sunk (5408 Allied and neutral ships), number of war patrols and U-boats lost. ${ }^{26}$ More sources useful for filling in details of Germany's efforts in communications intelligence from the First to the Second World War include the more than 29,000 pages of declassified material related to the Second World War era Target Intelligence Committee, now publicly available following recent transfers from NSA to the National Archives and Records Administration. ${ }^{27}$

The work of the Imperial Navy's communications intelligence organization, the Entzifferungs-Dienst (decryption service or E-Dienst), stayed largely untold until 1970 when Heinz Bonatz, the former chief of the Second World War era B-Dienst, published the first complete history of the navy's radio intelligence service in both

24 See Paul Gannon's assessment of the British intelligence records, Inside Room 40: The Codebreakers of World War I (Hersham UK: Ian Allan , 2010), 7-9.

25 Hans Joachim Koerver, ed., Room 40: German Naval Warfare 1914-1918, 2 vols. (Steinbach, 2008-2009). The British cryptographers noted that the organizational and coordination problems only began to improve towards the end of the war after the Admiralty made Room 40 part of the Admiralty's Intelligence Division. Koerver, Room 40, 1, xv-xvi, cited William F. Clarke's 1959 note that Room 40's history was in a "safe place" since its completion shortly after the war and noted Beesly's description of its status in his Room 40's "Sources and Select Bibliography" and in footnote two, 127, where he pointed out that the first two volumes (The Fleet in Action and The Fleet in Being) were in the Library of the Naval Historical Branch and he expected that the classified index, the third volume of "Contribution to the History of German Naval Warfare, Authorities" (which contains information on about 3000 of volumes of papers and records arranged collected by Frank Birch and Clarke and their working group) were likely to be released shortly by the Public Record Office. These documents, HW 7/1-4, and other Room 40 records are now located in the National Archives, Kew, UK.

26 Koerver, German Submarine Warfare, 34-161 and 651-705.

27 See Randy Rezabeck's TICOM: The Hunt for Hitler's Codebreakers (Rochester, NY: independently published, 2017), a detailed study of the Target Intelligence Committee operations and findings. 
world wars. ${ }^{28}$ Bonatz's purpose was to fill the gap in the historical record of the role of communications intelligence and present a balanced history of German successes as well as failures. Bonatz, however, had limited access to archival sources and primarily relied on the British and German official histories. His description of the navy's use of wireless and cryptography, however, closely followed the critical findings of the secret official German navy assessment of the influence of communications intelligence on the war at sea. Published under the auspices of the navy's staff officer (Führergehilfen) training program, Korvettenkapitän (Lieutenant Commander) Gustav Kleikamp's thirty-five page classified evaluation was one of a series of official studies exploring key operational and tactical aspects of the war. ${ }^{29}$ Following his analysis of the state of British and German technical development of wireless and their efforts to build radio intelligence services after the beginning of the war, Kleikamp studied each phase of the naval war, with a separate summary of the role of radio intelligence at Jutland in 1916. After a summary of the final period of war from Jutland to 1918, the report closes with a summary of the causes of the British intelligence and deciphering successes.

As scholars became increasingly aware of Kleikamp, especially after Beesly's 1982 work, they cited his sharp criticism of the navy's "careless" use of wireless and its failure to take decisive action in resolving its security problems after they first suspected and later learned that the British had compromised their codes. Although Kleikamp did credit the successes of E-Dienst in the First World War in gathering vital information on the enemy's activities and later strengthening its radio security, his critique highlighted the navy's poor state of preparedness for the revolution in naval warfare caused by wireless, and focussed on German weaknesses in communications intelligence (including organizational problems and operational procedures).$^{30} \mathrm{He}$ emphasized British codebreaking successes and their impact on German naval operations, primarily in the North Sea and at Jutland..$^{31}$ According to Kleikamp, the lack of results in the spring of 1915 for the High Sea Fleet led to an "almost complete abstaining from further operations" that

28 See Bonatz's Die Deutsche Marine-Funkaufklärung 1914-1945 (Darmstadt: Wehr und Wissen Verlagsgesellschaft, 1970) and his declassified report to the Office of Naval Intelligence, "The History, Development, Organization and Success of the German Naval Intelligence Service ("B-Dienst") During the Period Between the Two Wars," NARA, RG 457, HCC Box 604, NR 1571. Bonatz did not reference Kleikamp as a source in Marine-Funkaufklärung, 1914-1945.

29 Kleikamp had served as a junior radio officer in the German battlecruiser SMS Derffinger during the First World War and was director of the navy's Communications Research Command (Nachrichtenmittel-Versuchskommando) in the early 1930s. He was serving as a staff officer at the Fleet Command when he wrote this study.

30 Kleikamp cited the isolation of the main decryption center (in Neumünster) from Berlin, the Fleet Command and the North and Baltic Sea Naval Stations and delays in getting intelligence to the fragmented command structure as problems.

31 Kleikamp only briefly acknowledges the effect of communications intelligence in other theaters and on Zeppelin and U-boat operations, arguing that these experiences scarcely differed from those in the North Sea as to how the British exploited the weaknesses in German communications (e.g. he briefly blames the loss of so many U-boats on the navy's inadequate handling of communications). 
year. ${ }^{32}$ German efforts to defeat the British in detail had failed. In most cases Room 40 had alerted the Admiralty through intercepts of German orders and were already at sea before the High Seas Fleet had left their anchorages. ${ }^{33}$ As Kleikamp famously stated, in 1915, "the strategic effects of the British radio intelligence and our poor use of wireless could hardly be much greater" with the Imperial Navy "practically playing with an open hand." 34 This impact of communications intelligence adds another dimension to the debate over the inactivity of the High Sea Fleet in the First World War . An immediate consequence of this British intelligence coup was the Imperial Navy's determination to continue to press for the resumption of unrestricted submarine warfare to destroy the enemy's sea transport as the only direct means it could employ to force the British to sue for peace. ${ }^{35}$

Given the timing of this report (i.e. the rise of Hitler to power in 1933 and the increased emphasis on rearmament), Kleikamp's primary purpose was to deliver a strong message that the navy needed to build the organizational foundation for the further development of the naval communications intelligence service, as well as to make continuous technical improvements in the equipment and tools of radio intelligence if it was to avoid the errors and miscalculations of the past war. Like other naval officers, Kleikamp was aware that Hitler's political and military goals included removing the restrictions of the Versailles Treaty that particularly limited its personnel and armaments (e.g., the size of capital ships and the building of airplanes and submarines) ${ }^{36}$ In 1934, German naval rearmament was at the beginning of its expansion under the new government. Both naval officers and historians have criticized Kleikamp for being too "one-sided" or "unbalanced" focussing too much on British successes and German mistakes and too little on German successes, and that charge applies to his other writings. ${ }^{37}$ Yet his pronounced

32 Kleikamp, 18.

33 Lambert, 403. Room 40 gave the British fleet "twenty-four-hour notice of all except one sortie" from December 1914 to November 1918.

34 Kleikamp, 14-18.

35 Schröder, Die U-Boote des Kaisers (Bonn: Bernard \& Graefe, 2003), 86-88 and Michael Epkenhans, The Imperial Navy, 1914-1915, Jutland (Lexington, KY: University of Kentucky Press, 2015), 135-136. In the January 1916 priorities for waging war in the North Sea, the U-boat commerce war was the first of the "practical approaches" while "vigorous actions" by the fleet were the last. Nr. 185 Aufzeichnung des Kommandos der Hochseestreitkräfte, 2.3.1916, "Leitgedanken für die Seekriegführung in der Nordsee." Die deutschen Seekriegsleitung im Ersten Weltkrieg, ed. by Gerhard Granier, II, (Coblenz: Bundesarchiv, 2000), 83-86.

36 By September 1933, Raeder reported to the officer corps following an exercise, Hitler "repeatedly speaks of the necessary building of the fleet," Ansprache des Chef ML zum Abschluss der Gefechtsübungen der Flotte, (ML-A-Ia 27c II) Bundesarchiv-Militärarchiv (BAMA), Freiburg, Germany, M 100/35.

37 See Bonatz, Marine-Funkaufklärung, 75 and Heinrich Walle, "Die Anwendung der Funktelegraphie beim Einsatz deutscher U-Boote im Ersten Weltkrieg" in Stephan Huck, ed., 100 Jahre U-Boote in deutschen Marine: Ereignisse-Technik-Mentalitäten-Rezeption (Bochum: Winkler, 2011), 111. Admiral Marschall made a similar observation to Kleikamp's 1936 study of Skagerrak, Oberkommando der Kriegsmarine (809) “Winterarbeiten 1935/36”, 6 November 1936, BAMA, RM 8/1894. 
critical tone reflected the urgency in his call to action and coincided in 1934 with the navy's first stage of expanding the new B-Dienst both organizationally and in personnel. ${ }^{38}$

Helmuth Giessler's brief study in 1971 of the development of radio equipment and electronic sensors concentrated more on the technical aspects of the specialized equipment used for communications, direction-finding, navigation and detection from 1914-1945 than on their operational use. ${ }^{39}$ Rear Admiral Sigurd Hess traced that development and evolution from the war years and its evolution after 1918. He attributes the Imperial Navy's unwillingness to resolve its fragmented organizational issues to the lack of any comprehensive evaluation of its use of wireless in operations, tactics, and security problems. Hess also raised the larger question of the institutional culture of the German naval officer corps, and its "traditional" undervaluation of technology, as root causes in the hindering of the further development of electronic equipment and encryption/decryption. In part, this was a result of the officers' limited education in natural sciences and technical training and their readiness to leave such matters to specialists outside of their command structure and status. ${ }^{40}$

The state of the navy's technical capabilities (e.g. the internal debates over diesel and turbine propulsion systems) and their effect on the navy's performance in the First World War had also been a topic explored by Hans Linnenkohl in 1978. Linnenkohl argued that without the necessary technical and scientific background and training, Tirpitz and his officers were inclined to trust their own "intuition" towards adopting new technology over the expertise of engineers and scientists, thereby denying the navy potentially important new improvements or breakthroughs (e.g. failing to follow-up on an early forerunner of radar). ${ }^{41}$ Both Hess and Linnenkohl foreshadowed the need for historians to develop new methodologies to integrate technical history more closely with military history to

38 Kleikamp, 8. See Walle's observation "Die Anwendung der Funktelegraphie," 111 and Marcus Faulkner, "The Kriegsmarine, Signals Intelligence and the Development of the B-Dienst Before the Second World War," Intelligence and National Security 25:4 (August 2010), 521-546. In 1934, following a reorganization of the Naval High Command, B-Dienst relocated in Berlin as part of an independent, combined communications intelligence department (the Marinenachrichtendienst) and began to expand, adding new personnel on land and at sea and listening posts.

39 Helmuth Giessler, Der Marine-Nachrichten- und Ortungsdienst. Technische Entwicklung und Kriegserfahrungen (Munich: J.F. Lehmanns, 1971).

40 Sigurd Hess, “Marineführungssysteme," Die Deutsche Marine: Historiches Selbstverständnis und Standortbestimmung (Herford and Bonn: E.S. Mittler, 1983), 315-336. See also Roland G. Foerster and Heinrich Walle, eds. Militär und Technik. Wechselbeziehungen zu Staat, Gesellschaft und Industrie im 19. Und 20. Jahrhundert (Herford and Bonn: E.S. Mittler, 1992), one of the first studies supporting increased attention to the value of technical history for a more comprehensive and comparative study of the origins and process of innovation in naval technology and their application (or not) to naval warfare (including the interaction between scientists and engineers, industrialists and military leaders).

41 Hans Linnenkohl, Alternativen und Möglickeiten Deutscher Seemacht 1898-1918 (Viernheim: np, 1978). 
give new insights into the critical role of the interaction between technological changes and weapon systems.

In 2005, Hilmar-Detlef Brückner's article uncovered new details of the littleknown role of the Bavarian 6th Army's W/T Command (Funker-Kommando) in stimulating the development of the Imperial Navy's communications intelligence capabilities and organization. ${ }^{42}$ Using previously unknown files in the Bavarian Military Archive that had not been destroyed in the Second World War, enough records remained for Brückner to gain key insights in the creation and organization of the Funker-Kommando and their early breaks into encrypted British naval signals. Brückner revealed that while stationed near the English Channel in late 1914, Funker-Kommando 6, (with the critical assistance of a new enlistee Ludwig Föppl), made its first break in December 1914 against a code used by British Army units and Royal Navy ships, decrypting three Royal Navy messages regarding activity in the English Channel. ${ }^{43}$ Establishing itself as the leader in German cryptanalysis, Föppl's unit continued to break into various Royal Navy codes and ciphers, finally succeeding in reconstructing the Auxiliary Patrol (or A.P.) Code, a cipher used by Royal Navy ships in the Channel and along the southeast coast of England and the Allied Fleet Code in June 1915. These messages were all sent to the Navy Staff at the General Headquarters, who then sent the messages to the Admiralstab in Berlin and the High Sea Fleet in Wilhelmshaven. ${ }^{44}$ In doing so, Funker-Kommando 6 spurred Imperial Navy interest in the decryption and prompted the navy to send an officer to the Funker-Kommando to learn the decryption methods. This officer, Kapitänleutnant (Lieutenant) Martin Braune, would later be instrumental in setting up and running the Imperial Navy's own decryption service (E-Dienst).

Werner Rahn's succinct 2011 analysis of the German failures to resolve quickly the organization and management of its communications intelligence operations highlighted several issues. The lengthy delay before strengthening radio procedures and security handed a decisive advantage to the British, who could intercept operational orders and take countermeasures against pending German operations or those already-underway. ${ }^{45}$ Heinrich Walle's 2011 chapter on the use of wireless in the U-boat war offers the best introduction to the early development of wireless and its operational and security implications for German naval operations. Drawing upon Kleikamp's evaluation, he faulted the navy's insufficient consideration of the

42 Brückner, 1-22. Cf. Martin Samuels for his analysis of the breakthrough role played by Ludwig Föppl in the cracking of British naval codes and ciphers including those used in minesweepers and the Fleet, "Ludwig Föppl: A Bavarian Cryptanalyst on the Western Front" Cryptologia 40:4 (July 2016), 355-373.

43 Brückner, 6. Giessler credits the Army with overcoming the Navy's "blindness" to the threat that the enemy had the same opportunity to intercept and read the German radio traffic. Giessler, 24.

44 See Brückner, 9-12, and Samuels, 355-373. Föppl also decrypted the merchant ship cipher.

45 Werner Rahn, "Der Einfluss der Funkaufklärung auf die deutsche Seekriegführung im Ersten und Zweiten Weltkrieg" in Winfried Heinemann, ed. Führung und Führungsmittel. (Potsdam: Militärgeschichtliches Forschungsamt, 2011), 15-56. 
potential and vulnerabilities inherent in using wireless. He also attributes this to a limited knowledge of the physical properties of electromagnetic waves and the many factors that could affect wireless communications (e.g., transmitter power, receiver quality, antennas, and interfering signals). Walle pointed out that while the Germans succeeded in decoding British messages by October 1914, it was unaware of the enemy successes against their own codes until the beginning of 1915. Despite some inadequate half-measures to fix their security problems, they did not undertake a complete overhaul of their main codebook until shortly before the end of the war. ${ }^{46}$

Apart from certain sensitive intelligence documents and equipment destroyed at the end of the war by the navy (as occurred in 1945) or in the Revolution, the extensive files of the German naval archives remained intact, and most survived the end of the Second World War when the Americans and British captured them. They returned to Germany in the late 1960s under condition that the records would be accessible to the public (both the Americans and British would not release some sensitive files until later years) ${ }^{47}$ Newer studies have begun to mine the surviving naval intelligence files, such as Marcus Faulkner's pioneering article on the navy's determination to rebuild the infrastructure of the navy's communications intelligence service under the restrictive provisions of the Versailles Treaty and the poor economic situation. Faulkner's documentation makes it clear that the inter-war Reichsmarine undertook significant steps to strengthen both its foreign intelligence work and its communications intelligence service. ${ }^{48}$ Recently several graduate studies have also demonstrated the potential of the new records in the German military archives for expanding our understanding of Germany's development of communications intelligence. ${ }^{49}$

\section{New Research into the E-Dienst}

While Brückner's discovery of the Bavarian Army's role in the Imperial Navy's early German cryptologic efforts against the Royal Navy added significant

46 Walle, 107-130.

47 See Paul Gannon's assessment of the British intelligence records including those from the War Office's cryptanalytic bureau MI1(b) and Room 40 records that, unlike the Second World War files, have a "dearth" of administrative and technical files. The records of the E-Dienst are mostly intact, at least in terms of the files of the Admiralstab and the High Sea Fleet. Boghardt notes that N's files were "almost completely preserved."

48 Faulkner, 521-546. See also Jak P. Mallmann Showell's summary of the "Radio Monitoring Service" at the end of the war and its development before 1933, German Naval Code Breakers (Annapolis: Naval Institute Press, 2003), 15.

49 See Andrea Benesch's master's thesis published as, Ver- und Entschlüsselungsmethoden im Ersten Weltkrieg. Kryptografieeinsatz an der Westfront und in der Nordsee (Munich: Grinn, 2015), which examined the decipherment methodology used by the army and navy communications intelligence units and Heiko Suhr's doctoral dissertation, Wilhelm Canaris. Lehrjahre eines Geheimdienstchefs - Die Marinelaufbahn des späteren Admirals Wilhelm Canaris (1905-1934), Vechta Universität, Vechta, Germany, 2018. See Suhr's documentation of the sources available for following Canaris' naval intelligence service work in Spain 1915-1916. 
information on the development of E-Dienst, his main focus was the FunkerKommando in Lille/Roubaix, and his reliance on army sources limited the insights he could gain on the navy's cryptologic program. Apart from recent specialized articles as noted above, historians have yet to fully mine the E-Dienst files in the German Military Archive in Freiburg. ${ }^{50}$ New research, conducted over the past two years in the navy's intelligence files, sheds new light on the early development of communications intelligence in the Imperial Navy and the evolution of its organizational structure and operational focus (as well as including new details of the role of Funker-Kommando 6). ${ }^{51}$

The files indicate that the Imperial Navy's awareness of the value of decryption began as early as October 1914 when the High Seas Fleet commander, Admiral Friedrich von Ingenohl, asked the Admiralstab whether they were capable of decrypting British "Satzbuch" wireless messages. After receiving a positive reply, the Ingenhol tasked the 1st, 2nd, and 3rd Squadrons (three battleship squadrons) to carry out periodic collection of these signals, clearly with the intent of having them decrypted by the Admiralstab.$^{52}$ Despite the Admiralstab's response, there is no evidence in the German naval archives that would suggest that the Admiralstab could or did, in fact, decrypt British signals at this time. However, on 3-4 November 1914, the German battlecruiser raid on the British coastal town of Great Yarmouth provided the navy the first real opportunity to collect British operational signals. Rear Admiral Franz Hipper, commander of the Scouting Force (Befehlshaber der Aufklärungsschiffe), tasked the battlecruiser Moltke to monitor British wireless traffic during the operation. Although the High Seas Fleet was unsuccessful in decrypting the intercepted messages, Hipper's after-action report shows a clear grasp of traffic analysis, with an attempt to recreate British actions by identifying enemy call signs. ${ }^{53}$

The records of the E-Dienst further refine the timeline of the Funker-Kommando's decryption of British communications, revealing that the first break occurred not

50 As noted above, see Rahn and Walle's use of the Imperial Navy's intelligence records in their brief studies of the use of wireless for the U-boat war in 1914-1918 and the influence of Funkaufklärung in both world wars respectively.

51 Jason Hines, "The Development of German Naval Communications Intelligence 19141916," (master's thesis, Helmut Schmidt Universität, Hamburg, 2017).

52 Hochseekommando (G 4587) to Admiralstab Berlin, 02 October 1914; Admiralstab to Hochseechef, 10 October 1914; and Kommando der Hochseestreitkräfte (G 4543 F2), 10 October 1914, BAMA, RM 47/262.

53 Rear Admiral Franz Hipper, Befehlshaber der Aufklärungsschiffe (G 5300 F2) to Chef der Hochseestreitkräfte, "Beobachtungen und Bemerkungen zum F.T. Verkehr während des Vorstoßes der I. und II. Aufklärungsgruppe am 2.-4. November 1914," 5 November 1914, BAMA, RM 47/262. See Hipper's observations in his personal diary concerning wireless issues and his concern over having the fleet's messages intercepted and giving away their location and the need for minimizing use of the wireless. At the same time, he increasingly recognized the value of intercepting and decrypting the enemy wireless traffic. Hipper Nachlass, 3 November 1914, 1/42; 15 December 1914, 2/5; and 3 March 1916, 4/35, BAMA, N 162. 
in December (as Brückner stated) but rather in early November $1914 .{ }^{54}$ On 3 November, the Admiralstab forwarded a single-page report to the High Seas Fleet containing the cryptographic solution for a British cipher used by army wireless stations and for traffic between British army and Royal Navy stations. ${ }^{55}$ Classified most secret (Ganz Geheim), the report states that the cipher had been broken by a German army cavalry division that had been stationed opposite British army units for a prolonged period. While not definitive, the German army unit referred to in the report is presumably the Funker-Kommando's Roubaix unit. By late November, the first Royal Navy signals had been decrypted by the army and passed to the navy. The Admiralstab forwarded these to the High Seas Fleet, with the recommendation that since the cipher was clearly used in naval signals, a continuous monitoring of British W/T traffic would seem to promise great benefits. Consequently, the Admiralstab asked the High Seas Fleet to establish several stations to continuously monitor British W/T traffic. ${ }^{56}$

The E-Dienst's records also make clear that Funker-Kommando 6 was not the only army unit assisting the Imperial Navy. In November and December 1914, the large high-power wireless station at Cologne was also supporting the navy, sending both decrypted British messages to the Admiralstab as well as raw (undecrypted) messages, which the Admiralstab was then decrypting on its own (using the 3 November cipher solution) before sending them to the High Seas Fleet in Wilhelmshaven. ${ }^{57}$

In addition to illustrating the early support by Army W/T stations to the Imperial Navy, the 3 November Admiralstab report is notable for an additional reason: the Admiralstab was making a conscious decision to send decryption material to the fleet and to push for local decryption, instead of attempting to centralize the decryption effort at the Admiralstab or the headquarters of the High Seas Fleet. A more telling example involved a newly-discovered French code book, the "dictionnaire chiffré modèle 1912, Type A," which was captured by the army and made available to the navy. ${ }^{58}$ The code was believed to be still in force, and it was used not only by French military commanders but also by the chiefs of the 1 st, 2nd, and 3rd French battleship squadrons. Two days after forwarding the British cipher solution, the Admiralstab sent a letter informing the High Seas Fleet of the French codebook and requesting that any intercepted messages that seemed to conform to this code be sent to the naval staff at the General Headquarters for

\footnotetext{
54 Brückner, 6.

55 Admiralstab der Marine (A 9250 I), 3 November 1914, BAMA, RM 5/5245.

56 Rear Admiral Paul Behncke, Admiralstab (A 10432 I) to Chef der Hochseestreitkräfte, 22 November 1914, BAMA, RM 47/262.

57 Admiralstab der Marine (N.A. 517) to Hochseechef, 4 November 1914; Admiralstab to Hochseechef, 13 December 1914; and Admiralstab (A 11968 I) to Kommando der Hochseestreitkräfte, 19 December 1914, BAMA, RM 47/262.

58 Admiralstab (A 9376) to the Chef der Hochseestreitkräfte, 05 November 1914, BAMA, RM $47 / 262$.
} 
decryption. ${ }^{59}$ To anyone receiving this letter, it was clear that the French code book had been compromised and that the Imperial Navy was actively seeking to use the book to decrypt French naval traffic. Yet, rather than closely protecting this knowledge, the High Seas Fleet's responded by ordering two hundred copies of the letter for distribution to the ships and squadrons of the fleet to alert them to the new guidance..$^{60}$

This episode shows that the Imperial Navy was treating communications intelligence as a tactical source and not as a strategic or operational source of intelligence. This stands in marked contrast to the British approach. For the British Admiralty, communications intelligence was a strategic tool, not a tactical one, and they placed greater emphasis on protecting the valuable source to keep it ready for when it would allow the Grand Fleet to catch the High Seas Fleet at sea. The Admiralty restricted knowledge of Room 40 and its capability to only a handfull of its most senior admirals. Outside the Admiralty, only Admirals Jellicoe, Beatty, and Bacon (at Dover) and Commodore Tyrwhitt (at Harwich) had official knowledge of the intelligence (but not regular access to its products) ${ }^{61}$

The Imperial Navy's tactical mindset reflects the perception of the value of the intelligence collected. As the only traffic that the Imperial Navy had intercepted and decrypted by that time had been tactical messages from the British patrol forces along the southeast coast of England, these experiences reinforced the use of communications intelligence as a tactical tool. Since tactical information is by definition perishable, it would be assumed that the ships and U-boats of the fleet would be able to make the most effective use of such material. By pushing decryption material to the fleet, the fleet would be able to decrypt any intercepted messages themselves and then make the quickest use of the intelligence.

The Imperial Navy learned that as successful as the 3 November solution was in decrypting British coastal traffic, it was not useful in decrypting Grand Fleet signals. In early December 1914, Vice Admiral Reinhard Scheer, at that time commander of the 2nd Squadron, reported to the High Seas Fleet commander that in attempting to decrypt several intercepted British signals using the new cipher key, only one could be successfully decrypted: a 22 September signal related to the U-9's attack on the British armoured cruisers Aboukir, Cressy, and Hogue off the Dutch coast. All the other messages Scheer copied had been encrypted using a different key. ${ }^{62}$ In mid-December, Hipper reported similar experiences. Referring to the traffic collection during his raid against Yarmouth in early November, Hipper reported that the cipher solution was not effective in breaking the signals, assessing

\footnotetext{
59 Ibid.

60 Ibid., Hochseeflotte (G 5302 F2), 09 November 1914, BAMA RM 47/262.

61 Admiral of the Fleet Sir Henry Oliver, "Notes about Room 40," National Maritime Museum, Greenwich, UK, (NMM), OLV/8, f. 2.).

62 Vice Admiral Reinhard Scheer, Kommando II. Geschwader, 06 December 1914, BAMA, RM $47 / 262$.
} 
that they appeared to have an extra layer of encryption (superencrypted). ${ }^{63}$

Another factor that hampered the navy's effort to decrypt Grand Fleet traffic was the limitation of relying on German warships to collect these signals (the geographic position of Roubaix/Lille and Cologne did not allow them to collect traffic from the northern and eastern North Sea). Moreover, the High Seas Fleet also required those warships assigned to collect British signals to maintain coverage of the primary German fleet communications frequency at all times. As a result, this dual requirement ensured the monitoring of enemy signals would not be continuous but sporadic at best. ${ }^{64}$ This did not help fleet W/T operators who needed regular time on the target. Shore stations might have been part of the solution to the problem. By this stage of the war, the Imperial Navy already had multiple coastal W/T stations in the North Sea that together comprised the North Sea communications net (stations already existed on Borkum Island and at List, for example), however, these stations were not tasked with the collection of Royal Navy traffic. Instead, they were focussed on sending and receiving German fleet traffic. This lack of dedicated North Sea-based listening stations delayed German decryption efforts against the Grand Fleet and directly impacted the success of operations later in the war.

The Admiralstab sought to expand the existing network of listening stations near the English Channel once the Army had occupied Belgium Flanders..$^{65}$ By early January 1915, the German Marinekorps agreed to have W/T Station Antwerp (a subordinate station of the Marinekorps) monitor British naval W/T traffic noting that this was already being done, but other stations under Antwerp were only collecting as time permitted. ${ }^{66}$ The Marinekorps' (semi) independence within the navy as well as the army highlighted the problems with the separate theater and command structures of the Imperial Navy. This lack of a unified centralized command would later result in a degree of friction (lack of coordination and efficiency) in the dissemination of intelligence. ${ }^{67}$

63 Hipper, Befehlshaber der Aufklärungsschiffe (G 5820 F2) to Chef der Hochseestreitkräfte, 10 December 1914, BAMA, RM 47/262.

64 Konteradmiral von Rebeur-Paschwitz, II. B.d.A. (G 838) to I. Befehlshaber der Aufklärungsschiffe, 18 December 1914, BAMA, RM 47/262.

65 Behncke, Admiralstab (A 12667) to Kommando der Hochseestreitkräfte, 31 December 1914, BAMA, RM 47/262.

66 Marinekorps Generalkommando (GG 43 1b) to Kommando der Hochseestreitkräfte, 05 January 1915, BAMA, RM 47/262.

67 See Konrad Ehrensberger, Hundert Jahre Organisation der deutschen Marine 1890-1990 (Bonn: Bernard \& Graefe, 1993) 33-36 and Mark Karau's The Naval Flank of the Western Front: The German MarineKorps Flandern 1914-1918, (Barnsley, UK: Seaforth, 2014). Flanders and the Baltic are two examples of the Navy's strategic shortcomings and its largely passive and defensive conduct of the naval war. Karau documents the inter- and intra-rivalries, particularly over resources, between the Marinekorps, the commanders of the High Seas Fleet, the naval, leadership in Berlin and the Army that resulted in Germany's failure to take advantage of the opportunities offered by the geographic advantages by the occupation of Flanders and the forces deployed by the Marinekorps. Karau also briefly describes several instances where codebreaking impacted operations but notes the 
While the Funker-Kommando in Roubaix/Lille was not the only organization supporting the Imperial Navy in decrypting British naval traffic, they were unique in the talent of their cryptologists, as Brückner points out and the original E-Dienst files clearly show. By late March 1915, Funker-Kommando 6 had uncovered the encryption key to a new, previously unseen Royal Navy cipher, referred to as the Auxiliary Patrol code. ${ }^{68}$ A similar cipher, the Merchant Vessel Cipher was broken shortly thereafter. In June, the Funker-Kommando successfully broke a three-digit code used by both British and French warships, dubbed the Allied Fleet Code by Lille. ${ }^{69}$

In July 1915, the navy decided to send an officer to Lille. Their motivation for doing so however was not alarm over the army's success, as suggested by Bonatz, or an army invitation to provide a professional evaluation as suggested in Brückner, but the navy's dissatisfaction with the army's dissemination of navyrelated messages. In mid-June 1915, Fregattenkapitän (Commander) Hermann Bauer, Führer der Unterseeboote (F.d.U. or "Commander of U-boats") complained in a letter to the High Seas Fleet commander that intelligence provided by FunkerKommando 6-and in particular British signals of value to U-boats operations arrived too late for the U-boat command to take advantage of it. ${ }^{70}$ Bauer proposed that a naval officer with experience in U-boat warfare be sent to Lille to take over the responsibility for deciding which messages were important enough to send to the navy. After receiving the approval of the High Seas Fleet and the Admiralstab, Kapitänleutnant Felix Gartmann, a wireless officer assigned to Kiel, reported for temporary assignment to the Funker-Kommando in Lille. Shortly after arriving, Gartmann recommended the creation of a Nachrichtenabteilung (intelligence section) at Lille with a naval officer as its chief..$^{71}$ The Admiralstab replaced Gartmann and appointed Kapitänleutnant Martin Braune, later considered the father of German naval communications intelligence, in August as chief of the newly-established Nachrichtenabteilung. ${ }^{72}$

By mid-November 1915, the idea of creating a naval-subordinated decryption service, an E-Dienst, was becoming more serious. On 11 November, the Baltic Sea Naval Station offered the High Seas Fleet the use of the existing W/T station at Neumünster (southwest of Kiel) as the location for the EntzifferungsHauptstelle (Main Decryption Center, shortened to E-Hauptstelle) and stated that

Marinekorps was unaware of British codebreaking efforts at the time.

68 Brückner, 10 and Kapitänleutnant Gartmann, Report from Funker-Kommando Nr. 6 (N.A. 126)

"Beobachtung des F.T. Verkehrs der Seestreitkräfte durch Armee Funkenstationen und Einrichtung einer Nachrichten-Abteilung beim Funker-Kommando Nr. 6," 24 July 1915, BAMA, RM 47/264.

69 Brückner, 11; Funker-Kommando Nr. 6 (N.A. 126) of 24 July 1915.

70 Führer der Unterseeboote (G 4507 F) to Kommando der Hochseestreitkräfte, 18 June 1915, BAMA, RM 47/264.

71 Funker-Kommando Nr. 6 (N.A. 126) of 24 July 1915.

72 Kiel-Station to Hochseechef, 21 July 1915, BAMA, RM 47/248. There is little information on Braune in current literature beyond brief assessments of his key role in developing the new naval intelligence organization, see Jak P. Mallmann Showell, 7, and David Kahn, Seizing the Enigma, 34. 
operations there could commence by mid-February. ${ }^{73}$ In a letter to the chief of Army Telegraphy-West on 09 December, the Admiralstab officially announced its intent to use the experience it had gained in Lille to create a new main decryption centre to target the communications of the Grand Fleet. ${ }^{74}$ Braune would become chief of the new command. ${ }^{75}$ A decryption station (E-Stelle) was established at the airship airfield at Tondern (modern Tønder, just north of the German-Danish border), to focus on North Sea traffic. The Marinekorps-subordinate W/T station in Bruges became E-Stelle West, focussing on British traffic in the Channel and along the southeast English coast. And a new station in Libau (modern Liepāja) focussed on Russian activity in the Baltic. These three stations were responsible for monitoring and decrypting enemy communications in their respective areas of responsibility; the main decryption station at Neumünster was responsible for the technical exploitation of the decryption results of the three stations. ${ }^{76}$ Critically, however, the new E-Stellen were required to transmit and receive German fleet signal traffic, ensuring constant monitoring of the operational nets, in addition to their main task of monitoring and decrypting enemy communications. ${ }^{77}$ This requirement would prove a major distraction during fleet operations.

By February 1916, the Admiralstab had established the final organization of the E-Dienst and officially informed the Kaiser of the E-Dienst's existence and had begun to provide on-going reports published by the E-Hauptstelle. ${ }^{78}$ On 20 May, the Admiralstab issued an "Instruction for the Decryption Service" (Anweisungen für den Entzifferungsdienst), laying out the tasks, sources, and distribution plan for the E-Hauptstelle and E-Stellen, along with providing general guidance on such matters as the strict secrecy of the program. ${ }^{79}$ The instruction laid out the administrative and operational chains of command for the E-Hauptstelle and the E-Stellen, and it further delineated the specific areas of interest for each of the stations. It was also very clear in the importance it placed on the new source of intelligence, saying, "the decryption of enemy wireless messages represents the

73 Kiel Station (3296 A) to Hochseekommando, 11 November 1915, BAMA, RM 47/264.

74 Chef des Admiralstabs der Marine (A 24434 I2) to the Feldtelegraphenchef West, Großes Hauptquartier, 09 December 1915, BAMA, RM 47/264.

75 Captain Friedrich von Bülow, Admiralstab (A $2355 \mathrm{I}^{2}$ ) to the Staatssekretär des ReichsMarine-Amts, 28 January 1916, BAMA, RM 47/264.

76 Ibid.

77 “Ergebnis der Besprechung am 26 Januar 1916," BAMA, RM 47/264

78 Admiral von Holtzendorff, Chef des Admiralstabes der Marine (A $4257 \mathrm{I}^{2}$ ) to Seine Majestät den Kaiser und König, 17 February 1916 in Item 5986, British and Allied Naval Reports of First World War by German Naval Radio Intelligence to 1918 Vol I and Vol II; NARA, Records of the National Security Agency/Central Security Service, Record Group 457; Archival and Historian's Source Files, 1809-1994 (Entry P-11); and E-Hauptstelle Neumünster, "Beobachtung des englischen F.T. Verkehrs in der Zeit von 1.-15. Februar 1916," (Umdruckschreiben Nr. 467), 25 February 1916, BAMA, RM 51/7.

79 Chef des Admiralstabes der Marine (A $\left.14204 \mathrm{I}^{2}\right)$ to Kommando der Hochseestreitkräfte, 20 May 1916, BAMA, RM 47/264 and “Anweisungen für den Entzifferungsdienst," Admiralstab der Marine (A $14204 \mathrm{I}^{2}$ ), May 1916, BAMA, RM 51/7. 
fastest, most reliable, and most extensive intelligence source that we have." ${ }^{\circ 0}$

In summary, the navy's records, while they document a slow and tentative start in decrypting British naval communications, confirm the considerable progress the Imperial Navy had made after receiving the support of Army cryptologists in Lille, both in achieving key break-throughs against British encryption and by training navy cryptologists. By the end of May 1916, the E-Dienst was standing on its own feet and seemed ready to support operations against the Grand Fleet. The key components of the E-Dienst were in place: the three decryption centres (in Tondern, Bruges, and Libau) had received the necessary $\mathrm{W} / \mathrm{T}$ receivers and transmitters and were operational. A main decryption center had been established in Neumünster with the Imperial Navy's most experienced cryptologist at the helm. Supported by a network of direction-finding and monitoring stations, the centers received raw intercepted messages (still encrypted) and bearings of Admiralstab's Instructions of 20 May 1916, collection guidance and reporting procedures were in place, codifying the earlier developed relationships and practices.

Yet, despite the considerable improvements, the new E-Dienst still faced severe challenges. Although the Funker-Kommando in Lille had achieved the near-total penetration of the simpler codes used by British patrol and coastal forces, the encryption used by the Grand Fleet was much more complex, especially the most critical signals, making their signals more difficult to decrypt. Braune had made inroads in the encryption, but with limited success. ${ }^{81}$

\section{Conclusion}

In many ways, the newly-formed E-Dienst was the antithesis of Room 40. Whereas Room 40 became a centralized organization by the Fall of 1914 with a clear mission and under the direct control of the Admiralty, the E-Dienst had become centralized only in 1916. However, any benefits brought by centralization were effectively neutralized by the dual tasking forced on the E-Dienst by the High Seas Fleet's requirement to monitor German fleet communications while carrying out their Admiralstab-directed collection of British signals. These competing assignments divided the attention of the E-personnel and lessened their time on target, reducing their effectiveness and making it more difficult for E-personnel to gain the necessary experience with British communications to allow further breaks in British encryption. Worse, when intercepting enemy communications during battle was more critical, the W/T operators of the E-Stellen would also be responsible for tracking the exploding number of their own communications. This lack of centralization and mission clarity unnecessarily complicated the E-Dienst's effort to focus on its main mission of decrypting enemy messages.

As Kleikamp's official assessment of the Imperial Navy's communications

80 Ibid.

81 Braune, E-Hauptstelle Neumünster (747E) to Kommando der Hochseestreitkräfte, 26 March 1916, BAMA, RM 47/264. 
intelligence during the war made clear, these shortcomings were less damning than the Imperial Navy's lack of effective operational security for its own communications. The lengthy delay in changing their codes and addressing lapses in security protocols (e.g. frequency, distribution and centralized oversight of all communications) allowed Room 40 to continue its successful codebreaking efforts for a much longer period than otherwise would have been possible. Focussing less on German successes in decryption, Kleikamp's post-war evaluation also offers valuable insight into the not fully understood impact of Room 40's "demoralizing" effect on German surface operations, especially the High Seas Fleet's "playing with open cards in 1915." 82 Kleikamp's final admonition in his critique, directed towards the navy's future leaders and officers, was that only "careful planning in peacetime" would avoid repeating the Imperial Navy's failure, for three years, to recognize and institute changes in its radio security. As Patrick Beesly summed up in his assessment of the British and German "war in the ether" --"Victory comes to the side that makes the fewest mistakes, and the Germans made many more in the Wireless War than did the British." 83

While the studies cited in this article have contributed to a better understanding of the early development of the German naval decryption service in First World War, the examination of the available intelligence files in the German naval archives and other documents released in recent years reveal the impact of the German efforts to organize its naval cryptology services, its perception of the value of intelligence for tactical use and its choice of methods (encryption philosophy) and abilities (cryptanalytic philosophy) and provide the foundation to address one of the significant lacuna in the history of German naval communications intelligence. By bringing together these records along with a variety of diverse sources, we can broaden our understanding of the interaction of the Imperial Navy's communications intelligence as part of the larger cultural, technical and strategic context of military intelligence as it evolved in the First World War and its influence on future developments. ${ }^{84}$

82 See Pöhlmann's assessment of the impact of Room 40 on the operations of the High Seas Fleet in "German Intelligence at War" 54.

83 Beesly, 33. The renowned German computer scientist, Friedrich L. Bauer notes that the history of cryptography shows that the "unauthorized decryptor feasts on the mistakes of the adversary," citing encryption processing errors, tactical and strategic faults at higher command levels and issues of organization: Friedrich L. Bauer, Decrypted Secrets: Methods and Maxims of Cryptology (Berlin: Springer, 1997), 405.

84 Pöhlmann points out the variety of existing and new sources that could offer new questions and perspectives "Towards a New History of German Military Intelligence," 1-8. 